\title{
Manifestations of the Flu Syndrome in Medical Students during the COVID-19 Pandemic
}

\author{
Manifestações da Síndrome Gripal em Acadêmicos de Medicina Durante a Pandemia \\ COVID-19
}

\author{
Tânia Gisela Biberg-Salum*abc; José Luis Quelho Filhoc; Gabriela Freitas Sorrilha'; Pietro Delgado Rezendec; \\ Eduarda Oliveira Celeric; Mylla Silva Braga ${ }^{\mathrm{c}}$
}

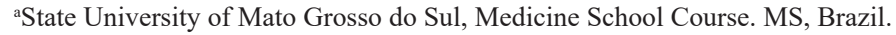 \\ ${ }^{\mathrm{b}}$ Anhanguera Uniderp University, Stricto Sensu Post-Graduate Program in Science and Mathematics Teaching. MS, Brazil; \\ ${ }^{\mathrm{c}}$ Anhanguera Uniderp University, Medicine School Course. MS, Brazil. \\ *E-mail: tania.salum@anhanguera.com \\ Recebido em: 30/09/2020 \\ Aprovado em: 03/12/2020
}

\begin{abstract}
Infection caused by the new Coronavirus (SARS-COV-2) causes a variable clinical feature. Due to its high transmissibility, Covid-19 was declared a pandemic. In view of this, in Brazil, the Ministry of Education (MEC) published an ordinance that temporarily suspended face-toface activities at Higher Education Institutions (HEIs). Despite this and other measures, the number of cases and deaths in Brazil has, so far, has increased exponentially, a fact that impacts the health and educational authorities, due to the exceptionality imposed on the development of teaching activities. Because of such context, the present study aimed to measure the frequency of the Flu Syndrome in medical students from Mato Grosso do Sul during the Covid-19 pandemic period, in order to propose resolutions for conducting academic activities. A descriptive, observational and cross-sectional study carried out among students enrolled in medicine school courses in the state of Mato Grosso do Sul. The data were obtained through a semi-structured, online questionnaire and based on the Google Forms platform. Descriptive results were prepared automatically, from the platform itself. Result: 371 responses were computed. Approximately $50 \%$ had flu-like symptoms, the most common of which were runny nose, nasal obstruction and cough. Among the diagnoses reported, the most described one was rhinosinusitis, with 7 participants presenting Covid-19. It was possible to measure the condition of flu-like syndrome among medicine school students in this state, seeking to provide support and possible basis for decision-making by the medical courses coordinators in Mato Grosso do Sul regarding the referral of academic activities.
\end{abstract}

Keywords: Coronavirus. Students, Medical. Disease Notification.

\section{Resumo}

A infecção causada pelo novo Coronavírus (SARS-COV-2) causa quadro clínico variável. Devido à sua alta transmissibilidade, decretouse estado de pandemia pela Covid-19. Diante disto, no Brasil, o Ministério da Educação (MEC) publicou portaria que suspendeu, temporariamente, as atividades presenciais nas Instituições de Ensino Superior (IES). Apesar desta e de outras medidas, o número de casos e óbitos no Brasil continua, até o momento, aumentando de forma exponencial, fato que impacta as autoridades sanitárias e educacionais, pela excepcionalidade imposta no desenvolvimento das atividades de ensino. Em face deste contexto, o presente trabalho teve como objetivo mensurar a frequência da Síndrome Gripal em academicos de medicina do Mato Grosso do Sul durante o período da pandemia da Covid-19, para assim, propor resoluções para condução das atividades acadêmicas. Um estudo descritivo, observacional e transversal, realizado entre estudantes matriculados nos cursos de medicina do estado de Mato Grosso do Sul. Os dados foram obtidos por questionário semiestruturado, online e assentado na plataforma Google Forms. Os resultados descritivos foram elaborados automaticamente, a partir da própria plataforma. Computou-se 371 respostas. Aproximadamente 50\% apresentaram algum sintoma gripal, sendo os mais comuns: coriza, obstrução nasal e tosse. Entre os diagnósticos informados, o mais descrito foi rinossinusite, sendo que 7 participantes apresentaram Covid-19. Foi possível mensurar o quadro de sindrome gripal, entre estudantes de medicina neste estado, buscando proporcionar apoio e eventual embasamento para a tomada de decisões das coordenações dos cursos de medicina do Mato Grosso do Sul quanto aos encaminhamentos das atividades academicas.

Palavras-chave: Coronavirus. Estudantes de Medicina. Notificação de Doenças.

\section{Introduction}

The infection caused by SARS-CoV-2 is a zoonosis and, despite the lack of extensive information on the virus natural history, analyzes of its genomic sequencing indicate that the host reservoir would be the bat, even if the way the virus migrated from animal populations to humans remains undetermined $^{1}$. COVID-19 was first introduced as a viral outbreak in Wuhan, central Province of Hubei, China, in December $2019^{2}$. In this period, a group of about 40 cases of pneumonia of unknown etiology was reported, including among the affected, seafood market sellers and dealers in the city of Huanan. In view of this scenario, the World Health Organization (who) worked together with the Chinese authorities and soon established the etiologic agent as a new virus, named New Corona Virus (2019-nCoV), which triggers a variable clinical feature, typical of the Influenza-like Syndrome, which varies from mild symptoms, such as fever, cough and sore throat until a severe presentation, involving 
respiratory failure ${ }^{3}$. Meanwhile, on January $11^{\text {th }}$, the Chinese government announced the first death related to COVID-19, a 61-year-old man previously exposed to the seafood market ${ }^{4}$. After a few weeks, the infection spread rapidly to other provinces in China and subsequently to a growing number of other countries, which led WHO to declare COVID-19 pandemic in March of this year after the virus affects around 114 countries $^{5}$.

As a result of these events, the Brazilian government has taken measures to prevent the spread of the new respiratory virus, starting a "contingency scenario" ${ }^{6}$. One of the control actions adopted was the suspension of face-to-face activities in schools and colleges in Brazil. In this scenario, MEC published the in order to authorize the use of digital media and technologies for the temporary replacement of classroom classes in higher education institutions (IHE) for a temporary period, with the objective of mitigating the damage caused by the pandemic and maintaining the routine of student studies ${ }^{7}$.

However, despite control and management measures in different areas in Brazil, the country is currently one of the epicenters of the Covid-19 pandemic, with number of cases and deaths per million inhabitants growing exponentially ${ }^{8}$. According to $\mathrm{WHO}^{9}$, on May 22 ${ }^{\text {nd }}, 2020$, there were 4.993.470 confirmed cases of Covid-19 in the world, with 327,738 deaths. In Brazil, by 05/23/2020, the Ministry of Health ${ }^{10}$ had recorded 347,398 cases, which characterizes an incidence rate of 165.3 cases for every 100 thousand inhabitants. On the same date, Brazil had accumulated 22,013 deaths confirmed by coronavirus (mortality rate of 10.5/100 thousand inhabitants). The state of Mato Grosso do Sul is in a rapid growth in the number of cases, with 13.461 patients confirmed until 07/13/2020, according to the State Board of Health ${ }^{11}$.

According to Barrucho ${ }^{8}$, due to lack of testing, the country is unable to estimate the pandemic proportion in a truthful manner and, as there are far fewer reported cases, the disease mortality rate seems higher, when it may actually be lower, causing this rate to reflect basically the hospital mortality rate $^{12}$. Thus, the country is in challenging circumstances, which reflect uncertainties in many areas, among them the indecision about the return of face-to-face academic practices.

In view of the scenario of underreporting of coronavirus cases among the medicine school researchers, a deadlock is established as to whether or not curricular activities are resumed, since if precipitated and based on an illusory number, such a decision could lead to the progression of the virus transmission, thus contributing to the pandemic expansion and consequently an increase in the number of deaths. In view of this, knowing and measuring the percentage of students affected by COVID-19 is an essential tool to help not only the deans' offices of medicine school universities to deliberate on the academic year future, but also the scientific community and health agencies, thus favoring the screening of suspected cases and probable transmitting individuals.
The objective of this study was to measure the prevalence of signs and symptoms characteristic of the influenza-like syndrome in medicine school students undergraduate students from Mato Grosso do Sul during the Covid-19 pandemic period, in order to verify the quantitative values of those affected by signs and symptoms of the flu syndrome during the Covid-19 pandemic, to identify the prevalence of influenzalike syndrome without an etiologic diagnosis established among the students from the medicine school upper education in Mato Grosso do Sul and to elucidate contributing factors for the absence of diagnosis in the face of the possible signs and symptoms of the influenza-like Syndrome.

\section{Material and Methods}

This is a quantitative, observational, descriptive and crosssectional study using primary data. The research took place in a virtual environment, with forms sent via e-mails (electronic mail), carried out with the students of medicine school courses, from the first to the sixth year ( $1^{\text {st }}$ to $12^{\text {th }}$ semester), from the Universities of Mato Grosso do Sul (UEMS - State University of Mato Grosso do Sul, Brazil), UFGD - Federal University of Grande Dourados, UFMS - Federal University of Mato Grosso do Sul and Anhanguera University - Uniderp). The convenience sampling technique was used, since the research was carried out by means of an online form. Considering the number of enrolled students in the above courses for which the forms were sent, a $n$ of 327 participants was estimated, calculated from a sample value with an error margin of 5\% and a confidence interval of $95 \%$.

The study included the forms completed by students over 18 years old, regularly enrolled in the medicine school course at universities in the state of Mato Grosso do Sul (UMS, UFGD, UFMS and Anhanguera-Uniderp), who signed the TCLE. The exclusion criteria were: students under 18 years of age, students who were not regularly enrolled in the medicine school course of the universities of the state of MS and those who did not sign the TCLE, in addition to the forms that were inadequately completed.

Regarding the data collection instrument, a semi-structured questionnaire was used, made available online, developed by researchers, using Google forms (Google Inc. forms platform). The attached Free and informed consent form (TCLE) has been made available. The link of these documents was sent by e-mail to the academic centers of the medicine school universities of Mato Grosso do Sul: Academic Center of State Medicine (CAME Medicine UEMM); Academic Center Camilo Ermelindo da Silva (CACES Medicine UFGD); Academic Center of Medicine Günter Hans (CAMGH Medicine UFMS); Academic Center of Medicine Dr. Vespasiano Barbosa Martins (CAMU Medicine Uniderp), and thus, passed on to the students of the institutions addressed.

Therefore, the medicine school students from Mato Grosso do Sul, by clicking on the link, were automatically 
directed to the study and TCLE information. After accepting to participate in the research and consenting to answering it, a set of questions arose sequentially, so that the participants would answer, objectively selecting the most appropriate options for their context. The following questions were asked: sex, age, university of origin, presence or not of signs and symptoms of Influenza-like syndrome in the last 90 days, contact or not with suspected/confirmed cases of Covid-19, obtaining or not diagnosis in the face of the signs and symptoms presented, and the reason for the absence of diagnosis, if it occurred. Finally, the participant submitted the completed form, whose responses were processed together with the others.

The data were collected in July 2020, only online after the authorizations were granted by the Ethics in Research Committee's consent under opinion number 4.144.778. The forms information was tabulated and analyzed using the data and graphs generated by the application instrument itself (Google forms), in which all the variables mentioned above were included.

\section{Results and Discussion}

The data were collected from the online questionnaire, which received 371 replies. All the participants agreed to continue the research and agreed with the TCLE. All participants who responded to the questionnaire met the study inclusion criteria, so it was not necessary to delete any form. Of the respondents, $67.1 \%$ were female, while $32.9 \%$ were male. Most were in the 18-23-year-old age group (281 responses - 75.7\%), followed by the 23-30-year-old group, with 75 participants and $4 \%$ older than 30 years. As for the university of origin, 198 were students from Anhanguera-Uniderp University, while the others were divided, 88 from UEMS, 51 from UFMS and 34 from UFGD, as shown in Figure 1.

Figure 1 - University of origin of the research participants.

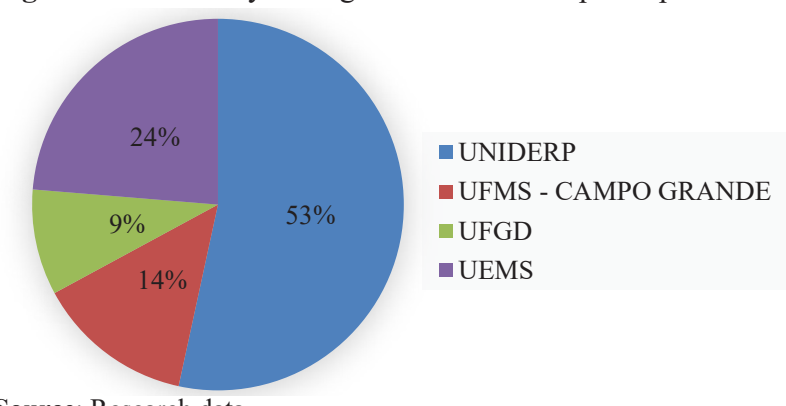

Source: Research data.

Regarding the signs and symptoms of influenza-like syndrome, manifested in up to 90 days before the survey, $45.9 \%$ of the interviewed students denied any symptoms, while $54.1 \%$ reported several manifestations. Of these, the most frequent was upper respiratory symptoms (coryza, nasal obstruction), followed sequentially by cough, odynophagia, gastrointestinal symptoms and myalgia and fatigue, as shown in the percentage of Figure 2. Less frequent, but also present, were: dyspnea, fever (above $37.8^{\circ} \mathrm{C}$ ) and arthralgia $(3.2 \%$ ).

Figure 2- Signs and symptoms pointed out by the research participants.

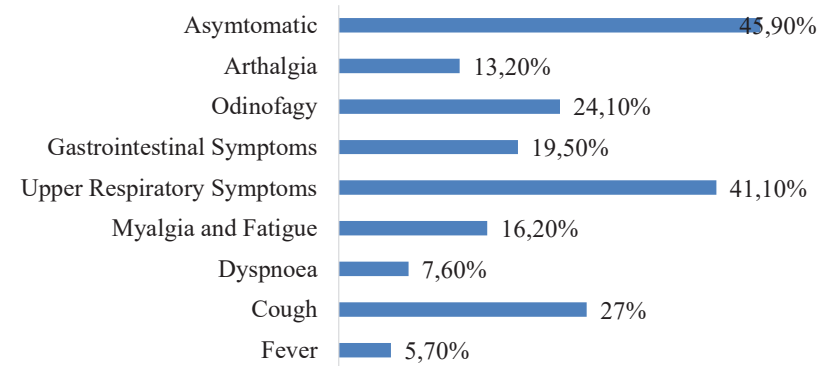

Source: Research data.

In view of the 201 students who presented signs and symptoms, 30 of them, or $14.9 \%$, received specific diagnosis. Of these, 17 reported having had a diagnosis of viral rhinosinusitis, another seven had a diagnosis of Covid-19, five of bacterial rhinosinusitis and one of H1N1 influenza. The others, $85.1 \%$, reported not having received diagnosis as shown in Figure 3. The alleged reason for this in a total of 133 of them was that they did not seek medical assistance, another 16 reported that there were no examinations available, thinking about the diagnostic differential of Covid-19, and the others mentioned other unspecified reasons.

Figure 3 - Diagnoses pointed out by the research participants

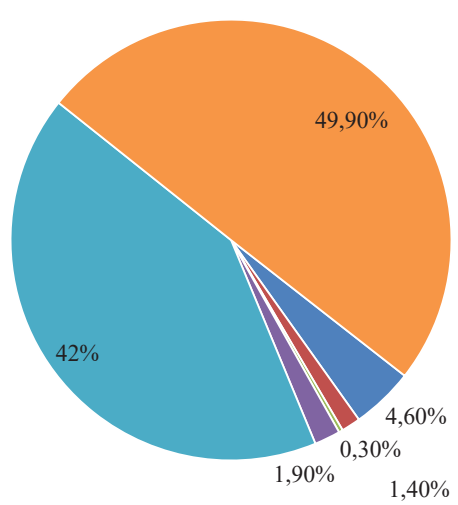

Source: Research data.

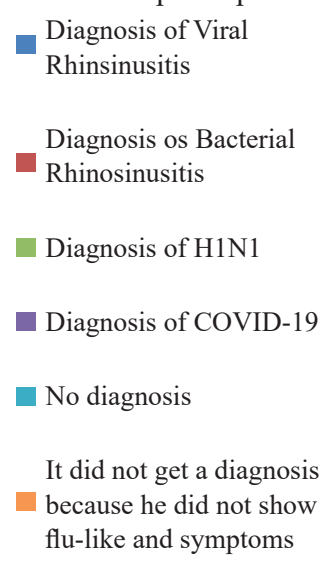

When asked about the possible contact with suspected and/or confirmed cases of Covid-19, 65.9\% of the participants reported that they had no contact whatsoever, while $19.2 \%$ had contact with suspected cases, $8.1 \%$ with confirmed cases and $6.8 \%$ had contact with both, suspect case and confirmed case as shown in figure 4.

Figure 4- Scenarios pointed out by the research participants.

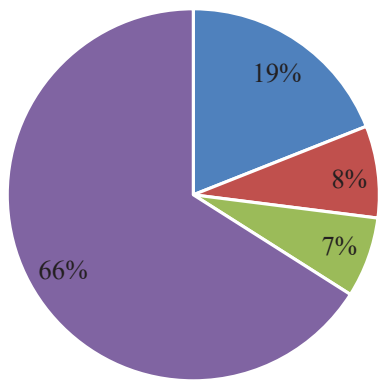

- Contact with suspected case of COVID-19

- Contact with confirmed case of COVID-19

- Contact with suspected and confirmed case of COVID-19

- Had no contact with suspected case and confirmed case of COVID-19

Source: Research data. 
In the case of the seven students who presented confirmed diagnosis of Covid-19, they were all female and from Uniderp college, being $71.4 \%$ aged between $18-23$ years and $28.6 \%$ older than 30 years. Regarding the signs and symptoms presented by them, the most frequent complaint was upper respiratory symptoms $(71.4 \%)$, followed by myalgia and gastrointestinal symptoms (both with 57.1\%), cough (42.8\%), arthralgia (28.6\%) and, less frequent, fever and odynophagia $(14.3 \%)$, as shown in figure 5. One student, diagnosed with the new coronavirus, mentioned that he did not present symptoms. Regarding the contact scenario of these students, all reported having had contact with cases of Covid-19, with $57.2 \%$ reported contact with only the confirmed case, while the other $42.8 \%$ reported contact with the suspected case and confirmed case.

Figure 5 - Signs and symptoms presented by number of students diagnosed with Covid-19

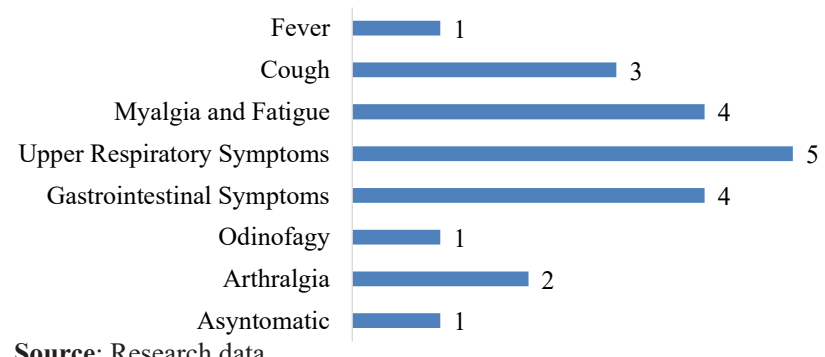

Source: Research data.

Therefore, the prevalence of signs and symptoms of Influenza-like Syndrome found was $54.1 \%$ among medicine school students in Mato Grosso do Sul who contributed to the research, with the upper respiratory symptoms being the most reported, present in $41.1 \%$ of the cases. In addition, $85.1 \%$ of the students who presented influenza-like features did not obtain specific diagnosis, mainly due to lack of demand for medical care and, to a lesser degree, due to the lack of available diagnostic tests, for diagnostic differential of Covid-19.

Based on the results presented, it was found that, among the students participants in the research, the majority are female $(67.1 \%)$, aged between 18 and 23 years $(75.7 \%)$. It is observed that the proportion of female respondents to this study is higher than that found in the Brazilian population in general, which is composed of $51.8 \%$ of female individuals, demonstrating their interest and availability for participation in the research. ${ }^{13}$

Considering that, in the present study, the majority presented manifestations of upper airways, such data are compatible with the influenza-like syndrome when compared to those presented in the literature, as pointed out by the Ministry of Health ${ }^{3}$ Although only $5.7 \%$ of the students presented fever, COVID-19 may be suspected due to complaints such as cough, odynophagia and mild respiratory symptoms, since fever may not be present in some cases of the new pathology ${ }^{14}$.

Most of the individuals affected by the new coronavirus present mild symptoms ( $80 \%$ ), with only about $20 \%$ of the cases requiring hospital care ${ }^{14}$.

Among the students who presented symptoms, only $14.9 \%$ received specific diagnosis, and 3\% (7 participants) were diagnosed with COVID-19, showing that the vast majority did not obtain diagnosis because they did not seek medical assistance $(66.5 \%)$ and a small portion reported that they did not have access to diagnostic tests $(8 \%)$.

The low diagnostic index, reported by the research participants, favors the underreporting of cases by SARSCov-2 and the increased virus spread, as evidenced in China, where it is estimated that $79 \%$ of the documented cases were contaminated by underreported patients ${ }^{15}$. In addition, Brazil has a low-test rate, making it difficult to access diagnostic tests, as present in some cases of research participants, not testing mild cases to the detriment of those with higher severity ${ }^{12}$.

In view of this, the prevalence of students who presented signs and symptoms during this period is notable, having only a minority of individuals sought to diagnose before the frame. Despite the pandemic of the new coronavirus, this study found a low frequency (1.9\%) of this pathology, which may have happened due to the difficulty accessing the diagnostic tests for this disease, the fact that the sampling used was non-probabilistic and, also, by the majority of participating students being young, may have presented mild symptoms, which did not motivate them to seek medical care.

Also, before the students who affirmed the Covid-19 diagnosis, all were female and the majority (71.4\%) were female in the 18-23-year-old age group. A higher proportion of cases were expected in women, since in the state of Mato Grosso do Sul, $51.9 \%$ of those affected by this pathology were female ${ }^{11}$, however, the proportion found in the study participants was substantially high. The age group with the most affected ones in the state was 30-39 years ${ }^{11}$, diverging from the results found in the research.

It can also be inferred that there was a low prevalence of the most common symptoms and signs of this pathology. There was a higher prevalence of symptoms and signs of upper airways in counterpoint to those with more commonly associated to coronavirus: fever (temperature $\geq 37.8 \mathrm{C}$ ), cough, dyspnea (respiratory difficulty), myalgia and fatigue ${ }^{16}$. Furthermore, this contrast between the most common symptoms of the disease and those presented by the students reveals an expected anomalous behavior for symptomatic cases of COVID-19, which can contribute considerably to the underdiagnosis and underreporting of the number of cases. It is also worth pointing out that the cases presented probably sought medical assistance because they had had contact with confirmed case of coronavirus.

Taking into account the high frequency of signs and symptoms of the influenza-like syndrome and the possible rate of underreporting and underdiagnosis among medicine school students in this study, the importance and necessity of the realization and fulfillment of the social distancing 
measures becomes evident, since even simple symptoms of upper airways, such as coryza and sneezing, may be associated with COVID-19 and these patients may be responsible for contamination of an important portion of the community.

Regarding the academic context, the lack of diagnosis and the underreporting noted by the results of this research are alarming elements and should be taken into account by the coordination of universities, aiming not only at the students' protection, but also of future patients they will attend, cooperating with the restraint of the pandemic and the decrease of the low-test influenza-like syndrome dissemination among the students.

\section{Conclusion}

This research made it possible to understand the frequency of signs and symptoms of influenza-like syndrome among medicine school students from Mato Grosso do Sul during the covid-19 pandemic. Therefore, it was possible to realize that the need to implement new measures before the possible return to classes of the medicine schools of this study, considering the results, which point to a marked amount of the frequency of students affected by these symptoms and signs of the influenza-like syndrome in this period.

Thus, it is proposed to adopt measures of individual prevention to students and professors, with an emphasis on the use of protective equipment such as masks and gloves. In addition, measures of collective protections are also proposed by the institutions, such as keeping the environment ventilated by natural ventilation, performing systematic cleaning and disinfection of room surfaces, increasing access to Alcohol in Gel, restricting the number of people in spaces of common use, and maintaining attention to students, professors and employees who present fever and respiratory symptoms, are indispensable actions for the conscious and safe return of curricular activities before this scenario ${ }^{17}$.

Thus, prioritizing the containment of the pandemic progression and decreasing the incidence rate of signs and symptoms of the influenza-like Syndrome among the students. At this moment, it is considered that there is a need and reinforcement of theoretical virtual activities and before the correct measures to prioritize return to practical activities, since these, besides acting to structure knowledge, make it possible for the future physician to insert into scenarios that bring it closer to the real and indispensable experiences for his or her formation ${ }^{18}$.

\section{References}

1. Mackenzie JS, Smith DW. COVID-19: a novel zoonotic disease caused by a coronavirus from China: what we know and what we don't. Microbiol Aust 2020;41(1):45-50. doi: https://doi.org/10.1071/MA20013.

2. Holshue ML, DeBolt C, Lindquist S, Lofty KH, Weisman J, Bruce H, et al. 2020 First case of 2019 novel coronavirus in the United States. N Engl J Med2020;382:929-36. doi: https://doi.org/10.1056/NEJMoa2001191
3. Brasil Ministério da Saúde. Secretaria de Atenção Primária à Saúde (SAPS). Protocolo de manejo clínico do coronavírus (COVID-19) na atenção primária à saúde. Brasília: SAPS; 2020.

4. Welle D. China tem $1^{\mathrm{a}}$ morte por misteriosa pneumonia viral. [access in 17 jul 2020]. Available in: https://g1.globo. com/mundo/noticia/2020/01/11/china-tem-1a-morte-pormisteriosa-pneumonia-viral.ghtml .

5. OPASBrasil.OMS afirmaqueCOVID-19éagora caracterizada como pandemia. [access in 17 jul 2020]. Available in: https://www.paho.org/bra/index.php?option=com content\&view=article \&id=6120:oms-afirma-que-covid-19e-agora-caracterizada-como-pandemia \&Itemid $=812$.

6. Peduzzi P. [Internet]. Coronavírus: ministro e secretários discutem plano de contingência [access in 17 jul 2020]. Available in: https://agenciabrasil.ebc.com.br/saude/ noticia/2020-02/coronavirus-ministro-e-secretariosdiscutem-plano-de-contingencia.

7. Lima L. MEC autoriza ensino a distância em cursos presenciais. [access in 17 jul 2020]. Available in: http://portal. mec.gov.br/component/content/article?id=86441.

8. Barrucho L. Brasil: o novo epicentro da pandemia de coronavirus. [access in 17 jul 2020]. Available in: Disponível em: https://www.bbc.com/portuguese/brasil-52732620.

9. OPAS Brasil. Folha informativa-COVID-19 (doença causada pelo novo coronavírus). [access in 17 jul 2020]. Available in: https://www.paho.org/bra/index.php?option=com_con tent $\&$ view $=$ article $\&$ id $=6101$ : covid $19 \&$ Itemid $=875 \#$ datasnoticificacoes.

10. Brasil. Ministério da Saúde. Painel Coronavírus. [access in 17 jul 2020]. Available in: https://covid.saude.gov.br/.

11. Mato Grosso do Suk. Secretaria do Estado de Saúde/ Governo do Estado de Mato Grosso do Sul. Boletim Coronavírus. [access in 17 jul 2020]. Available in: https://www. vs.saude.ms.gov.br/wp-content/uploads/2020/07/BoletimEpidemiol\%C3\%B3gico-COVID-19-2020.07.13.pdf.

12. Barrucho L. Brasil: o novo epicentro da pandemia de coronavírus?. [access in 17 jul 2020]. Available in: https:// www.bbc.com/portuguese/brasil-52732620.

13. IBGE. Diretoria de Pesquisas, Coordenação de Trabalho e Rendimento, Pesquisa Nacional por Amostra de Domicílios Contínua 2012-2019. [access in 5 ago 2020]. Available in: https://educa.ibge.gov.br/jovens/conheca-o-brasil/ populacao/18320-quantidade-de-homens-e-mulheres. html.

14. Brasil. Ministério da Saúde. Guia de Vigilância Epidemiológica: emergência de saúde pública de importância nacional pela doença pelo Coronavírus 2019. [access in 17 jul 2020]. Available in: https://portalarquivos.saude.gov.br/ images/pdf/2020/April/07/GuiaDeVigiEpidemC19-v2.pdf

15. Li R, Pei S, Chen B, Song Y, Shang T, Yang W, et al. Substantial undocumented infection facilitates the rapid dissemination of novel coronavirus (SARS-CoV-2). Science 2020;368(6490):489-93. doi: https://doi.org/10.1126/science. abb3221

16. Moehlecke Iser BP, Silva I, Raymundo VT, Poleto MB, Schuelter-Trevisol F, Bobinski F. Definição de caso suspeito da COVID-19: uma revisão narrativa dos sinais e sintomas mais frequentes entre os casos confirmados. Epidemiol Serv Saúde 2020. doi: https://doi.org/10.5123/S167949742020000300018. 
17. Secretaria de Saúde/ Governo do Estado. Nota Conjunta Saúde e Educação: medidas de prevenção da infecção pelo COVID-19 nas escolas e universidades. [access in 5 ago 2020]. Available in: http://www.saude.ba.gov. br/2020/03/09/medidas-de-prevencao-da-infeccao-humanapelo-novo-coronavirus-covid-19-dirigidas-a-comunidade- escolar-e-universitaria/

18. Batista NA, Batista SHSS. A prática como eixo da aprendizagem na graduação médica. In: Puccini RF, Sampaio LO, Batista NA. A formação médica na Unifesp: excelência e compromisso social. São Paulo: Unifesp; 2008. p.101-15. 